Prof. Stephen Church,

School of History,

University of East Anglia,

Norwich, NR4 7JJ

\title{
THE DATE AND PLACE OF KING JOHN'S BIRTH TOGETHER WITH A CODICIL ON HIS NAME
}

John's birthday is traditionally given as 24 December $1167 .{ }^{1}$ This is the date that William Stubbs established in $1873,{ }^{2}$ and, for more than a century, it has been the date that is generally accepted. In 1902, Kate Norgate followed Stubbs on assigning the date of John's birth to Christmas Eve 1167, and she further placed John's birth at 'the King's Manor' at Oxford, in other words 'Beaumont House'. ${ }^{3}$ In 2004, John Gillingham accepted both this date and place of birth. ${ }^{4}$ Others have been less steadfast in their adherence to the date even if no-one (until 2002) questioned the place. In his 1961 biography of King John, W. L. Warren gave 1166 as the year of his subject's birth, though by 1973, when he had come to write the biography of John's father, Henry II, Warren had fallen into line with accepted opinion. ${ }^{5}$ In 1994, Ralph V. Turner

1 Handbook of British Chronology, ed. E. B. Fryde, D. E. Greenway, S. Porter, and I. Roy, (London, 1986), 37.

2 Memoriale Fratris Walteri de Coventria, ed. W. Stubbs, 2 vols, Rolls Series (London, 1872-3), II, xvii-xviii note 3; see also his The Historical Works of Master Ralph de Diceto, Dean of London, Rolls Series, 2 vols (London, 1876), I, xliv.

3 Kate Norgate, John Lackland, (London, 1902), 1 \& n. In 1887, Norgate had acknowledged the problem of determining between 1166 and 1167, but deferred, in the end, to Stubbs (Kate Norgate, England under the Angevin Kings, 2 vols (London, 1887), II, 130-1 note. 7).

4 John Gillingham, 'John (1167-1216)', Oxford Dictionary of National Biography, (Oxford University Press, 2004; online edn, Sept 2010

[http: / / www.oxforddnb.com/view/article/14841, accessed 22 January 2020].

5 W. L. Warren, King John, (London, 1961), 17; W. L. Warren, Henry II, (New Haven, Ct, 1973) 78; F. Barlow, The Feudal Kingdom of England, 2nd edn, (London, 1961), 332, 
agreed, giving John's birth to the traditional date of December 1167; by 2009, however, he had changed his mind and was now firmly placing John's birth at Christmastide 1166, possibly 27 December, though Turner stated that the place of John's birth admitted of doubt. ${ }^{6}$ In 2015, Marc Morris felt himself unable to decide on the date of John's birth, having John 'being born probably around Christmas 1166 - or possibly $1167^{\prime} .{ }^{7}$

Morris was right to be hesitant. In assigning John's birth to 1166, Turner had been following too closely A. W. Lewis, who, in 2002, had explored some of the evidence for John's birth and upbringing, but his conclusions had been less certain than Turner's use of them would suggest. Lewis had examined the chronicle evidence along with the itineraries of Eleanor and of her husband concluding that 'the converging lines of evidence point to 1166 as the probable year of John's birth', though he felt that he had to admit that 'there would seem to be no sure way to establish a preference between [1166] and [1167]'. Of the location of John's birth, Lewis concluded that 'England [was] the place'. ${ }^{8}$ The continued circumspection of the editors of the authoritative Oxford Dictionary of National Biography (its on-line presence meaning that changes to John Gillingham's entry could be made if it were thought the case was proven) suggests further that those who have withheld final judgment have been wise to do so. ${ }^{9}$ Not-with-standing that counsel of

unaccountably has John's birth as occurring in October 1165. This error was later 'corrected' to 24 December 1167 (5th edn, 276).

6 R. V. Turner, King John, (London, 1994), 20; idem, Eleanor of Aquitaine: Queen of France; Queen of England (New Haven, Ct, 2009), 143.

7 M. Morris, King John: Treachery, Tyranny, and the Road to Magna Carta, (London, 2015) 19.

8 A. W. Lewis, 'The birth and childhood of King John: some revisions', in Eleanor of Aquitaine: Lord and Lady, ed. B. Wheeler and J. C. Parsons, (London, 2002), 159-75 (at 165). 9 In 2015, I stated unequivocally that 'John was born at the end of 1166, or early 1167, at the Tower of London.' (Stephen Church, King John: England, Magna Carta, and the Making of a Tyrant (London 2015), p. 1). In this article I seek to lay out my reasons for having done so and to correct an error that I made. 
caution, in 2016, David Crouch launched himself decisively into the debate with two footnotes in his third edition of William Marshal in which he stated categorically that John was born at Gillingham, Dorset, on 27 December 1167, and raised there in an Anglo-French family. ${ }^{10}$

There are two near-contemporary testimonies concerning John's birth. The first is by Ralph de Diceto, who was certainly in England by the 1160s, having beforehand spent some time as a scholar at Paris and then becoming archdeacon of Middlesex in the diocese of London from 1152x3 until his election as dean of St Paul's in 1180. He had been at the Council of Northampton in 1164, and he had played a bit-part in the Thomas Becket crisis, being asked by Richard of Ilchester, one of Henry II's senior administrators, about the validity of Becket's sentence of excommunication against Henry's friends. Ralph was evidently trusted by the king and his intimate advisors, being at the least on the periphery of royal power. ${ }^{11} \mathrm{We}$ may think of Ralph, therefore, at the point in his career when John was born, as a man who moved in the sorts of circles that would have allowed him to

10 David Crouch, William Marshal: Knighthood, War, and Chivalry, 1147-1219, 3rd ed, (London, 2016), p. 88 notes 5 and 6. Gillingham as the place of John's birth he derives from the fact that in 1212 in Gillingham Hundred, Dorset, a certain William Baillebien held '3 virgates of land which King John's father gave him in alms because he rocked him [that is John] in his cradle (quia berciavit illum)' (cf Dictionary of Medieval Latin from British Sources, 'berciare', which uses this particular example). Crouch takes this entry in the Book of Fees to mean that John was raised in Gillingham by William Baillebien as his foster-child (Liber Feodorum: The Book of Fees commonly called Testa de Nevill, 3 vols, (London, Public Record Office, 1920-31), II, p. 91). It seems to me that this interpretation requires a rather large leap of interpretive imagination if we are to accept that it is evidence that John was born in Gillingham and that William Baillebien was his foster-father who raised him in an AngloFrench speaking family before he went to Fontevraud. Roger of Howden thought that John's first home after the cradle was in the household of the Young King Henry (Gesta Regis Henrici Secundi Benedicti Abbatis, 2 vols, ed. W. Stubbs, Rolls Series (London, 1867), I, 7). Crouch also stated that Gerald of Wales's testimony that when he went to Ireland in 1185 John was 17 is decisive in dating his birth to 1167 (Expugnatio Hibernica, ed. A. B. Scott and F. X. Martin, (Dublin, 1978), 227).

$11 \quad F a s t i$ Ecclesiae Anglicanae 1066-1300: St Paul's London, ed. D. Greenway, (London, 1968), 14-17 (cf British History Online http: / / www.british-history.ac.uk/ fasti-ecclesiae/10661300/vol1/pp14-17 [accessed 22 January 2020]); W. Stubbs, 'The Historical Works of Master Ralph de Diceto', in Historical Introductions to the Rolls Series, ed. A. Hassall, (London 1902), 35-88. 
have heard at first hand when the queen gave birth to her children. ${ }^{12}$ His statements in his headings for his Images of History and in the main text of his chronicle are clear: in 1166, 'Alienor regina peperit filium quem vocavit Johannem'.${ }^{13}$ Most medieval commentators followed Ralph's lead in placing John's birth in 1166 with some adding the extra information that the birth took place at the end of the year. ${ }^{14}$ One anonymous chronicler, a canon of Laon, was bold enough to assign a date 'about the time of the feast of St John' (27 December) adding that it was his birthdate that got him his name. ${ }^{15}$ There is, though, a taint attached to Ralph's testimony. After a detailed examination of Ralph's chronology for the 1160s and early 1170s, William Stubbs was forced to the conclusion that 'the chronology of our author, even when he professes to have taken particular pains, is not to be accepted without suspicion of carelessness, and that such carelessness as shows that the notes for this part of his work were not contemporaneous... [even if], when compared to the Gesta [Regis Henrici Secundi of Roger of Howden],

12 In his Abbreviatio, Ralph noticed the births of Henry under 1155, Matilda under 1156, Richard under 1157 (where he stated unequivocally that the boy was born at Oxford), Geoffrey under 1158, Eleanor under 1162 (wrongly for she seems to have born in 1161), and Joanna under 1165. (The Historical Works of Master Ralph de Diecto, Dean of London, ed. W. Stubbs, 2 vols, Rolls Series, (London, 1876), I, 268-70).

$13 \quad$ Ralph de Diceto, I, 271 and repeated on p. 325.

14 Ralph de Diceto, I, 325. Ralph placed the notice of John's birth between two letters relating to the Becket dispute which are dated by their modern editor as being issued in early July 1166 (Correspondence of Thomas Becket, Archbishop of Canterbury, 1162-1170, ed. A. Duggan, Oxford Medieval Texts, (Oxford, 2000), nos. 95, 96). John was perhaps born around the feast of St John the apostle (27 Dec and see note 15 below) which Diceto may have mistaken for the feast of the birth of St John the Baptist (24 June); see, for example, 'Annals of Dunstable', Annales Monastici, ed. H. R. Luard, 5 vols, Rolls Series, (London, 1864-69), III, 19.

15 Recueil des historiens des Gaules et de la France, 24 vols, (Paris, 1734-1904), XIII, 679. The context of the canon's statement about John's birth is a description of the division of his lands made by Henry II in 1169. After telling his reader the details of the division and about the marriages made by Henry and Eleanor's daughters, the chronicler states that 'because he was born about the feast of St John, they named him John' ('quia circa festum S. Johannis natus fuit, Johannem appellaverunt'). Since the chronicler seemed to think that John was born after the division of Henry's lands ('quia vero natus est postquam pater suus terras inter fratres diviserat, Johannem sine terra eumdem cognominaverunt'), he should not be, therefore, considered a source of unimpeachable authority. 
Ralph's work is more exact on English affairs. ${ }^{16}$ Indeed, Ralph seems to have mistaken the date of the birth of the second of the royal daughters, Eleanor, placing it in 1162, and made an error in her place of birth, locating it at Rouen. ${ }^{17}$ Robert of Torigny, the second of our authorities for the births of the royal children, places Eleanor's at Domfront in 1161; since Robert acted as sponsor to the girl's baptism, he has been preferred as witness to her entry into the world. ${ }^{18}$

Robert was abbot of Le Mont-Saint-Michel on the border between Normandy and Brittany at the time of Eleanor's birth. He was obviously close to the Angevin family having secured his position at Mont-Saint-Michel by the patronage of Henry as duke of the Normans. His proximity to the court (he hosted Henry II on Le Mont on at least three occasions and knew the Empress Matilda personally) makes him a witness with real credibility. ${ }^{19}$ Perhaps not surprisingly, therefore, when Stubbs saw in the edition that he was using under the year 1167 that 'natus est Johannes filius regis Anglorum', ${ }^{20}$ he preferred what he assumed to be Abbot Robert's testimony to that of Dean Ralph. From this point onwards, John's birthday had the imprimatur of the greatest medievalist of the Victorian age.

Stubbs explained his thinking concerning John's birthday in an extended footnote to his introduction to the edition of Walter of Coventry. Here

\footnotetext{
$16 \quad$ Ralph de Diecto, II, xli-xlii.

17 Under 1162, he wrote 'Anglorum regina filiam peperit apud Rothomagum, cui nomen suum imposuit et vocavit Alienor' (Ralph de Diceto, I, 306).

18 'Regina Alienor apud Donnum Frontem filiam peperit, quam Henricus presbyter cardinalis et legatus Romaniae ecclesiae baptizavit, et Archardus, episcopus Arbincensis, et Robertus, abbas Sancti Michaelis de Periculo Maris, cum aliis multis, de fonte susceperunt; et vocata est Alienor de nominae matris suae' (Chronicles of the Reigns of Stephen, Henry II, and Richard I, ed. R. Howlett, 4 vols, Rolls Series, (London, 1884-89), IV, 233).

19 Chronique de Robert de Torigni: Abbé du Mont-Saint-Michel, ed. L. Delisle, 2 vols, (Rouen, 1872-3), II, pp. ii-iv.

${ }_{20} \quad$ Chronicles of the Reigns of Stephen, Henry II, and Richard I, IV, p. 233.
} 
he told his readers that the edition of Robert of Torigny's work that he was using was one which he identified as simply 'ed. Pistorius, i, 903'..$^{21}$ The volume to which he referred is the Illustrium veterum scriptorium qui rerum a Germanis gestarum historias reliquerunt, 2 vols, ed. J. Pistorius, Frankfurt 1583-4, in one of its editions. ${ }^{22}$ The importance of this fact is that it preserves a copy of a transcript of Robert's Chronica which was published in 1513, the exemplar for which is now lost. This exemplar was a copy of the manuscript that is retained in the municipal archives at Avranches. ${ }^{23}$ The Avranches manuscript, while the modern editors would deny it the status of an autograph, ${ }^{24}$ does, nonetheless, have the character of a working copy with insertions and erasures in many hands, including one identified as belonging to Abbot Robert of Torigny himself. ${ }^{25}$ Significantly for the purposes of this discussion, it is only the manuscripts of Robert's Chronica that descend from the Avranches manuscript which have the date of John's birth. ${ }^{26}$ All other manuscripts of the Chronica omit this crucial piece of information. The edition that Stubbs used was descended from this Avranches manuscript.

Pistorius's edition of Robert of Torigny's Chronica obscured a major problem with the dating of John's birth. Had Stubbs had access to Leopold

$21 \quad$ Memoriale Fratris Walteri de Coventria, II, xvii-xviii, note 3.

22 Chronicles of the Reigns of Stephen, Henry II, and Richard I, IV, p. lxvi, note 1 (Illustrium veterum scriptorium qui rerum a Germanis gestarum historias vel annales posteris reliquerunt tomus unus. Ex bibliotheca Johannis Pistorii).

${ }_{23} \quad$ Avranches, Bibliothèque Municipale MS. 159, fo. 217v. I am grateful to Prof. Thomas N. Bisson for allowing me to see part of his edition of Robert of Torigny before it went to the press, for sharing his thoughts on the subject of John's birth, and for sending me photographs of the relevant folios of the Avranches manuscript.

24 Chronicles of the Reigns of Stephen, Henry II, and Richard I, IV, xl-xli; Chronique de Robert de Torigni, ed. Delisle, I, liii.

${ }_{25}$ B. Pohl, 'Abbas qui et Scriptor? The Handwriting of Robert of Torigni and his Scribal Activity as Abbot of Mont-Saint-Michel (1154-1186)', Traditio, lxix (2014), 45-86. I am grateful to Dr Benjamin Pohl for generously sharing his hard-earned expertise with me.

26 Chronicles of the Reigns of Stephen, Henry II, and Richard I, IV, lxvi. 
Delisle's 1872-3 edition, which used the Avranches manuscript as its base, ${ }^{27}$ he might have been alerted to the fact that the 'note [of John's birth] was added afterwards in [the Avranches manuscript]'. ${ }^{28}$ Richard Howlett's 1889 edition of the Chronica also drew attention to the fact that the notice of John's birth had been inserted in a hand that he thought 'fantastic' ${ }^{29}$ Both the new editor of Robert of Torigny, Thomas N. Bisson, and the scholar who has worked extensively with Torigny's manuscripts, Benjamin Pohl, agree that the hand that inserted the notice of John's birth is strikingly different from those around it, though it is a hand that has been found elsewhere in the Avranches manuscript and in other manuscripts associated with the scriptorium at Le Mont-Saint-Michel. In the opinion of Dr Pohl, it is not the hand of the author of the Chronica, Abbot Robert of Torigny. ${ }^{30}$ We are, therefore, here dealing with a later insertion made by an unknown scribe (hereafter referred to as the Avranches-Correcting Scribe), who was working at the behest of Abbot Robert. $^{31}$

Since Ralph de Diceto demonstrably used a copy of Robert of Torigny's Chronica for much of his work before the death of Thomas Becket (d. 29 December 1170), it seems that he did so from a copy that did not include the notice of John's birth. His copy was not one that relied on a version of the Chronica that had left Le Mont before the Avranches manuscript was

\footnotetext{
27 To be fair, Stubbs could not have done so since Delisle's edition was published in the same year that he wrote about John's birth.

$28 \quad$ Chronique de Robert de Torigini, ed. Delisle, I, 369.

29 Chronicles of the Reigns of Stephen, Henry II, and Richard I, IV, xli (for his working method on the Avranches manuscript), lix-lxii.

$30 \quad$ Pohl, 'Abbas qui et Scriptor?', 45-86.

31 G. Passabì, 'An Archaeology of Robert of Torigni's Chronica: the second redaction and change in political discourse', in Revue Bénédictine, CXXIX, (2019), 319-344 makes a cogent case for the rewriting of Torigni's chronicle to have been stimulated by contemporary political circumstances.
} 
annotated..$^{32}$ Since Ralph was evidently reliant on Robert's work until 1171

(though there is just a possibility that he was so as late as 1183), ${ }^{33}$ the

Avranches-Correcting Scribe's notice of John's birth must have been inserted

into the Avranches manuscript of Torigny's Chronica after Ralph de Diceto's

copy was made. 1171 is therefore our terminus post quem for the Avranches-

Correcting Scribe's addition. ${ }^{34}$ Our terminus ante quem is established by the

recent work of Benjamin Pohl who has argued that a manuscript of Robert of

Torigny's Chronica that is bound up in British Library, Cotton MS. Domitian

A. VIII, is a direct copy of the Avranches manuscript on which John's

birthdate hangs. Domitian A. VIII (which does have the date of John's birth as

1167 in a script that perhaps attempts to imitate the Avranches-Correcting

Scribe's hand) $)^{35}$ was made in $1182 .{ }^{36}$ The insertion by the Avranches-

Correcting Scribe of the date of John's birth into his manuscript must

therefore have occurred between 1171 and $1182 .{ }^{37}$ The Chronica is not,

$32 \quad$ Radulfi de Diceto, II, x. Though unfortunately this copy is now unidentifiable (W. Sparrow Simpson, 'Two Inventories of the Cathedral Church of St Paul, London, Dated Respectively 1245 and 1402', Archaeologia, 1 (1880), 439-524 (at 496-500)).

33 Radulfi de Diceto, II, vii. Ralph's notice is sandwiched between two letters of Thomas Becket, the one to Gilbert Foliot, bishop of London, assigned the number 96 in Correspondence of Thomas Becket, I, 426-41 and dated by Duggan to early July 1166; the other to the English bishops generally, assigned the number 95 (Correspondence of Becket, I, 388-425) also dated by Duggan to early July 1166. An inspection of the manuscript reveals that the notice is in the same hand as that which transcribed the letters is the same as that which wrote the manuscript as a whole. The manuscript makes it clear that there is no doubt that the author of this text placed John's birth in 1166 deliberately (Lambeth Palace Library, MS 8).

$34 \quad$ It should be noted that from 1162 to 1172 , the text of Diceto is much concerned with the Becket crisis (unlike Torigny, who virtually ignores it) and is, in Stubbs's view, 'very valuable as the work of an intelligent, comparatively impartial eye-witness, such as we know Ralph de Diceto to have been.' (Radulfi de Diceto, II, xii).

${ }_{35}$ British Library MS Domitian A VIII, fo. $79 \mathrm{v}$. I am grateful to Dr Pohl for allowing me to see a photograph of this folio of the manuscript.

36 B. Pohl, 'The Date and Context of Robert of Torigni's Chronica in London, British Library, Cotton MS. Domitian A. VIII, ff. 71r-94v', Electronic British Library Journal I (2016), 118.

37. It is at this point that the experts diverge: Dr Pohl's work suggests that the insertion happened as the work was being 'tidied up' for presentation to a wider public at the request of Abbot Robert of Le Bec-Herluin (d. 1179) at a point close to the terminus ante quem of 1182 and by the Avranches-Correcting Scribe who was not Abbot Robert. Prof. Bisson's work suggests that the insertion could have been completed as early as 1171-2 (pers. comm.). Prof. Bisson will explore the issues raised by the manuscripts in his forthcoming Oxford Medieval Texts edition. 
therefore, (pace Stubbs) the unimpeachable witness to John's birth that has been previously thought.

When he came to address the problem of John's birth, A. W. Lewis decided to try to understand Eleanor of Aquitaine's known whereabouts to see if that would enable him to distinguish between the testimonies of Dean Ralph and Abbot Robert. He noticed that Eleanor was in England on 30 November $1167 .{ }^{38}$ On that day, the sheriff of Hampshire, Richard de Limesia, dispersed from the revenues of his county the cost of transporting to the continent the king's treasure and the horses of the chamber. Southampton was the port of embarkation for Normandy, which therefore tells us that the treasure was destined for the duchy. ${ }^{39}$ So, too, was Queen Eleanor. The following entry, not, alas, dated, is the account for monies that the same sheriff spent on the cost of the carriage of the queen and her entourage by ship to Normandy 'by the king's writ' ${ }^{40}$ By Easter week 1168, Eleanor was in Poitou, in time for Henry to leave her (on 7 April) in charge of the county under the protection of Earl Patrick of Salisbury. ${ }^{41}$

It is possible to fill in at least part of the gap in the chronology between 30 November 1167 and 30 March (Easter Day) 1168 by reference to the marriage of Eleanor's eldest daughter, Matilda. She was betrothed to Henry the Lion, duke of Saxony, their marriage taking place on 1 February 1168 at the Westphalian cathedral of Minden. ${ }^{42}$ The girl must have left her family's care by the end of the Christmas festivities (6 January) to be at her wedding. ${ }^{43}$

\footnotetext{
$38 \quad$ Lewis, 'The Birth and Childhood', 163.

39 P. Chaplais, English Diplomatic Practice in the Middle Ages, (London, 2003), 220-1.

Pipe Roll 14 Henry II, 189.

Chronicles of the Reigns of Stephen, Henry II, and Richard I, IV, 235-6.

C. Bowie, The Daughters of Henry II and Eleanor of Aquitaine, (Turnhout, 2014), 69-70.

As his first event of the year, Robert of Torigny recorded that Henry held his

Christmas court at Argentan; he followed that immediately with his account of Matilda's departure for Saxony; and then he placed in his text a notice of the death of the count of
} 
We have long known that Matilda travelled to Normandy at some point in the summer of 1167, since the pipe roll account for Hampshire that year was rendered by a triumvirate of men who had held the county for one-third of the year, and who had paid for a ship which took Matilda across the sea. ${ }^{44}$ Historians have traditionally assumed that Matilda must have remained in the duchy until she was sent to her new husband, which is possible, but is by no means certain. The English pipe rolls record payments made against English revenues from the English counties, not on any other revenues. Matilda could easily have returned to England that autumn and we should expect no evidence of that journey to appear on the English pipe rolls. Given that the woman after whom she had been named, the Empress Matilda, died on 10 September 1167, there is at least one other good reason we can think of to explain the girl's trip to Normandy before the end of the accounting year (28 September). The empress was buried at Le Bec Herluin in the presence of her son (and Matilda's father), Henry II. ${ }^{45}$

The suggestion that Matilda returned to England after her grandmother's funeral is given added weight by an entry in the pipe roll that covers Michaelmas 1167 to Michaelmas 1168 and which seems to have been ignored (although known about) as evidence by scholars determined to keep Matilda in Normandy from September 1167 until her journey to Germany. ${ }^{46}$ In the account rendered in the autumn of 1168, Hugh of Dover, sheriff of

Flanders, Thierry of Alsace. The count died on 17 January 1168 (Chronicles of the Reigns of Stephen, Henry II, and Richard I, 234).

44 Pipe Roll 13 Henry II, 193-4.

45 M. Chibnall, The Empress Matilda: Queen Consort, Queen Mother, and Lady of the English, (Oxford, 1991), 173; the place of burial is given by Torigny (Chronicles of the Reigns of Stephen, Henry II, and Richard I, IV, 233).

${ }_{46} \quad$ Kate Norgate, 'Matilda, duchess of Saxony (1156-1189)', rev. Timothy Reuter, Oxford Dictionary of National Biography, Oxford University Press, 2004

[http:/ / www.oxforddnb.com/view/ article/18339, accessed 22 January 2020]; Bowie, The Daughters, 70. 
Kent, was allowed against his county farm monies paid out 'in passagium

filie Regis quando missa fuit in Saxon". It is certainly legitimate to translate 'passagium' as 'transport across water', and since the revenues of the sheriffdom were often directed to the expenses of cross-channel royal travel, the translation does no damage to the sense of the Latin. ${ }^{47}$ The sheriff was also allowed against his account the amounts he had paid out 'for a palfrey and fugator' (a horse trained especially for hunting) to enable Matilda to complete her journey by land. ${ }^{48}$ Allowing Matilda to have returned to England in the autumn of 1167 before departing again for the continent, this time crossing from Dover to Wissant, also permits us to accept the testimony of Gervase of Canterbury who tells us that Eleanor accompanied Matilda to the continent, leaving from Dover, to be handed over to her future husband's ambassador (Provost Baldwin of Utrecht). ${ }^{49}$ Gervase was a later contemporary of Dean Ralph and of Abbot Robert, and although he did not start writing his Chronicle until after 1188, he had been at Canterbury since he had been received into the community by Archbishop Thomas Becket in 1163, and so his writings about the 1160 s have a contemporary flavour. ${ }^{50}$ He placed Eleanor and Matilda's crossing from Dover at the end of his account of the year 1167 (which must be right given that the pipe roll evidence has Eleanor in England on 30 November). Gervase's first entry for the year 1168 is the record of Matilda's marriage to Henry duke of Saxony. ${ }^{51}$ The congruence of

\footnotetext{
$47 \quad$ Dictionary of Medieval Latin from British Sources, 'passagium' notes 5 and 6. $48 \quad$ 'ad perficiendum passagium filie Regis' (Pipe Roll 14 Henry II, 208); Dictionary of Medieval Latin, 'fugator', note 2.

$49 \quad$ K Jordan, Henry the Lion, (Oxford, 1986), 147.

50 Michael Staunton, The Historians of Angevin England, (Oxford, 2017), 109-14.

51 The Historical Works of Gervase of Canterbury, ed. W. Stubbs, 2 vols, Rolls Series (London 1879-80), I, 204-5. Robert of Torigny tells us that at Christmas 1167, Henry II 'held a great court in his New Hall at Argentan' (Chronicles of the Reigns of Stephen, Henry II, and Richard I, IV, p. 234). Henry, therefore, is unlikely to have made his farewells to Matilda at the point she was handed to Provost Baldwin.
} 
evidence, therefore, places Eleanor and Matilda in each other's company in England for Christmastide 1167-8, crossing from Dover to Wissant during or immediately after the festive season to meet Henry the Lion's embassy where Matilda was handed over to the safe-keeping of her new family. Eleanor would then have returned to England after releasing her daughter into the custody of Baldwin of Utrecht before crossing again to Normandy at some point before Easter week 1168 when she was to be found in Poitou. ${ }^{52}$

When the material for Eleanor's whereabouts is gathered together, therefore, it is apparent that, at the time the Avranches-Correcting Scribe claims she was giving birth to John, she was in fact chaperoning Matilda in the build-up to the marriage between her and Henry the Lion of Saxony. One might opine that, given Eleanor's experience in giving birth, she could have had the confidence to travel from Dover to Wissant just before John's birth (or just afterwards). This proposition is, however, untenable given the normal conventions that surrounded childbirth in Eleanor's age. ${ }^{53}$ John may have been her tenth child (and Eleanor had at least one miscarriage of which we know and there is a hint of a second, so there may have been more than eleven pregnancies), ${ }^{54}$ but child-bearing was a dangerous activity for ordinary women and queens alike, and the rules under which women of status gave birth appear to have been strictly enforced. ${ }^{55}$ She was required to withdraw

\footnotetext{
$52 \quad$ Suggesting that the second pipe roll entry for Eleanor in Pipe Roll 14 Henry II, 189, should be dated between January and April 1168.

${ }_{53} \quad$ Fiona Harris-Stoertz, 'Pregnancy and Childbirth in Twelfth- and Thirteenth-Century French and English Law', Journal of the History of Sexuality, XXI (2): Approaches to Childbirth in the Middle Ages, 263-281 (at 273-4) where the author points to the examples she found of pregnancy being used as a reason for not travelling.

$54 \quad$ Lewis, 'The Birth and Childhood', 165.

55 Becky R. Lee, 'Men's Recollections of a Women's Rite: Medieval English Men's Recollections Regarding the Rite of the Purification of Women after Childbirth,' Gender and History, XIV (2002), 224-41. What follows relies on Lee's work and my own reading of the protocols for the purification of the queen in the Liber Regie Capelle, ed. W. Ullman, Henry Bradshaw Society, (London, 1961), 72-3. The Liber was written in the Spring of 1449 by William Say, dean of the chapel royal (1449-68), in response to a request by Count Alvaro Vaz
} 
from the outside world six weeks before her expected date of delivery to be enclosed in a room that had been especially prepared for the event. ${ }^{56}$ After the birth, the mother remained confined for two months until she had gone through the ritual purification process that marked the moment that she was clean enough to return to the society of men. ${ }^{57}$ Medieval aristocratic women, therefore, both before and after pregnancy, were outwith the court for more than three months. For Eleanor to have disregarded these strictures would have imperilled her soul and her body, and would, moreover, have courted the opprobrium of polite society. There is no reason for us to suppose that she would have acted in such a high-handed and potentially dangerous way and we must, therefore, accept that each time she was pregnant, Eleanor was incapacitated for more than three months. A simple calculation means that if John were born in late December, Eleanor should have withdrawn to her birthing chamber at the end of October and emerged for the ritual purification ceremony at the end of February. The evidence of her activities in 1167-8 coupled with the conventions of her station, make it unlikely that John was born during that winter.

d'Almada, and it seems to reflect not just the rules of the chapel as William understood them but also as they were written down in a now-lost manual (or manuals) of etiquette from which William copied his text (Liber, 6-10). William Say's Liber is concerned with the duties of the chapel royal, and apart from the responsibility that it had for the religious routine of the royal household each day, it also had duties relating to other signal moments in the spiritual cycle, including the purification of the queen. The Liber tells us that on the sixtieth day after the birth of her child, the queen was to be received in procession into the Great Hall where she was to be ritually purified. After her churching ceremony, the queen and her courtiers were instructed to return to the birthing chamber there to celebrate her reinstatement into court life.

${ }_{56} \quad$ There are extant manuscript collections that deal with court ceremonial from the early years of the sixteenth century and which give instructions for the ceremony surrounding 'deliverance of the queen'. Walter Ullman noticed A Collection of Ordinances and Regulations for the Governance of the Royal Household, ed. [M. Lort et al.]., The Society of Antiquaries of London, (London, 1790), 125 (datable to the time of Henry VII and copied from a 'Harleian' manuscript 'No. 642'). There is another in the collection of the College of Arms, London, M 8, fos 32-32v.

57 Becky R. Lee, 'The purification of women after childbirth: a window onto medieval perceptions of women', Florilegium, XIV (1995-96), 43-55 (at 44, 47-9). 
Where was Eleanor in the winter of 1166-7? Robert of Torigny tells us (in the hand of the Main Scribe, so a pre-1171 witness to events) that, in October 1165, while Henry was in England, Eleanor was at Angers where she gave birth to a daughter, Joanna. The following Lent (Ash Wednesday fell on 9 March that year), according to Robert, Henry crossed into Normandy..$^{58}$ In July $1166,{ }^{59}$ Henry pressed the men of Le Mans and of Brittany because they had followed Eleanor's orders less enthusiastically than they should have done while he had been away in England.$^{60}$ Evidently on the completion of Eleanor's confinement sixty days after Joanna's birth (which would have ended in December 1165), ${ }^{61}$ the queen must then have moved from Anjou to Normandy where she acted as ruler in Henry's absence. She would, therefore, have been in Normandy to greet her husband just before the Lenten season of 1166 began. This seems to have been the moment that John was conceived, for in the autumn of 1166, Eleanor disappears from the chronicles and the record evidence (apart from three significant entries in the pipe roll for that year about which more below) until she reappears as an active participant in the affairs of 1167 ready to make preparations for her daughter's marriage to Henry the Lion. ${ }^{62}$ While it is certainly dangerous to argue $e$ silencio, in this instance, the silence for the autumn and winter of 1166-7 (combined with the

\footnotetext{
58 Chronicles of the Reigns of Stephen, Henry II, and Richard I, IV, 226-7; Ralph de Diceto, I, 318.

59. Warren, Henry II, 100-1.

60 Chronicles of the Reigns of Stephen, Henry II, and Richard I, IV, 228. The English pipe rolls say nothing of Eleanor's existence during the exchequer term 29 September 1165 to 28 September 1166 other than to mention the usual payments that were made to her from the accounts of Devon and of London and Middlesex, so she was apparently not with Henry in England (Pipe Roll 12 Henry II, 93, 130).

${ }_{61} \quad$ For the strictures on when marital coitus should not happen see J. A. Brundage, Law, Sex, and Christian Society in Medieval Europe, (Chicago, 1987), esp. 154-64. Coitus was prohibited during nursing and the Lenten period.

62. Turner, Eleanor of Aquitaine, 143.
} 
noise created by the evidence concerning Eleanor's activities in 1167-8) is deafening. The date of John's birth was Christmastide 1166-7.

The birthplace of John is, however, less firmly established. It is usual to give John's place of birth as the king's house in Oxford, later to be known as Beaumont Palace. ${ }^{63}$ But the earliest claim that Oxford had this honour is in a late addition to a manuscript of Robert of Gloucester's Chronicle held by the College of Arms. Thomas Hearne, the most distinguished editor of the Chronicle, used two manuscripts now held at the British Library as his base texts for his printed edition, Harley 201 and, ${ }^{64}$ when Harley 201 ran out on line 9529, Cotton Caligula A xi. ${ }^{65} \mathrm{He}$ also had access to a heavily augmented manuscript then (and still now) held in the College of Arms. ${ }^{66}$ This has a midfifteenth-century insertion into Robert of Gloucester's text stating that 'In the xiii yere [of the reign of Henry II] (19 Dec 1166 to 18 Dec 1167) queen Alionore, passyng oute of Normandie into Engelond, childed a sone atte Oxenforde, in the kynge's maner, that was cleped Johan, in the Cristesmasse eve' $^{6}{ }^{67}$

63 The Victoria History of the Counties of England: Oxfordshire, ed. C. R. Elrington, (London, 1979), IV, 304.

64 BL Harleian 201. This Wright identified as a late fourteenth-century manuscript (c. 1390-1400).

65 BL Cott. Caligula A xi. which Wright dated to c.1320-30. It has evidence of John Stowe's writing on fo. 164b and much evidence (printed by Hearne as Appendix Num vi) of the notations of Selden on the manuscript. From fol 131.

66 College of Arms, Arundel MS 58; Robert of Gloucester's Chronicle, ed. Thomas Hearne, 2 vols, (Oxford, 1724, reprinted 1810). Of this manuscript, Hearne said that 'I found not only the language of Robert of Gloucester to be altered throughout in it, but the work quite changed in several respects, by having some passages transposed, others omitted, and divers inserted that were never written by Robert of Gloucester, who was of different principles from this author. A great deal of prose history in English (partly taken from Geoffrey of Monmouth, partly from William of Malmesbury, partly from the Brute of England, Polychronicon, etc) is intermixed with this manuscript.' It is from this manuscript that the insertions (Hearne did not include them all, recognizing that many of the additions were fanciful) are taken and rendered as extended footnotes in Hearne's edition. He did not know the author's identity, but dated his work to the time of Henry VI (probably after 1448). The manuscript was lent to him by John Bridges and by the kind offices of John Anstis, Principal King of Arms (Robert of Gloucester, I, ed. Hearne, lii-liv).

${ }_{67} \quad$ College of Arms, Arundel MS 58, fo. 236r; Robert of Gloucester, ed. Hearne, II, 484 note. Stubbs thought that the footnotes to Hearne's edition of the Chronicle amounted to marginal 
If this fifteenth-century interpolation represents the earliest evidence that can be mustered to suggest that the place of John's birth was Oxford, then we need to think again and offer an alternative location. Perhaps the evidence of Eleanor's confinement during the time of John's birth appears, should we wish to see it, in the pipe roll for 1166-7 where the sheriffs of London and Middlesex were authorised to expend $£ 64$ on works on 'houses in the Tower of London and on the king's houses at Westminster, namely, a new hall and a chamber for the queen' and on which a further $45 \mathrm{~s}$. were spent making the windows and other fitments. The queen also received three strong boxes worth $33 \mathrm{~s}$. by the king's writ. ${ }^{68}$ The preparation of a chamber in which the expectant mother was to give birth was an important part of the ritual that accompanied childbirth. She and her companions would decorate the chamber and gather together 'to share special food and drink' and to gossip while they waited for the signs that the child was on its way. ${ }^{69}$ If we acknowledge that the tradition that John was born in Oxford is weak, we are left with the conclusion that the monies spent on the queen's rooms in London may well represent the cost of the decoration of the birthing chamber in which John was to be delivered into the world. John's brother, Henry, had been born at London, ${ }^{70}$ as had his elder sister Matilda. ${ }^{71}$ There is no reason,

notations, but a look at Thomas Hearne's introduction to his edition would have alerted Stubbs to Hearne's methodology (Memoriale Fratris Walteri de Coventriae, I, xvii, note 3). Small wonder, then, that the Rolls Series edition does not have this, nor any other, additions from the College of Arms text (The Metrical Chronicle of Robert of Gloucester, ed. W. A. Wright, 2 vols, Rolls Series, (London, 1887), II, 676 lines 9589-600). The date is given by A. Gransden, Historical Writing in England c. 550-1307, (London, 1974), 432-8; see also Catalogue of the Arundel Manuscripts in the Library of the College of Arms, [ed. W. H. Black] (London, 1829), 10410.

68 'in operatione domorum Turris London' et domorum Regis de Westm', scilicet, noue aule et cammare Regine... et pro faciendum fenestris cammarum Regine et aliis minutis operibus... et pro iii paribus coffrorum ad opus Regine' (Pipe Roll 13 Henry II, 1, 2, 3).

${ }_{69} \quad$ Lee, 'Men's Recollections of a Woman's Rite', 227.

$70 \quad$ Chronicles of the Reigns of Stephen, Henry II, and Richard I, IV, 183.

$71 \quad$ Ralph de Diceto, I, p. 302 notes the date, the Annals of Waverley the place (Annales Monastici, II, 237). 
therefore, why Eleanor should not have chosen London (either the Tower or Westminster) to give birth to John.

The date of John's birth was, therefore, at Christmastide 1166-7, and its place was the queen's chamber in a newly built hall in London. The pipe roll entry does not allow the confidence I once gave it to decide whether that chamber was in a new hall at the Tower or in a new hall at Westminster. ${ }^{72}$ As to John's name, the explanation may well be found at the family monastery of Fontevraud. Established by Robert d'Arbrissel in the early twelfth century, the community was ruled by women throughout its history. The principal monastery of the community was dedicated to the Virgin, but that which housed the men who served the community was dedicated to St John the Evangelist. The community, moreover, was founded by Robert on the basis of the text of St John the Evangelist concerning the crucifixion of Christ in which Mary stood with 'the disciple whom He loved' and as Christ said to his mother 'woman, behold thy son' and 'after that, he saith to the disciple: Behold thy mother. And from that hour, the disciple took her to his own. ${ }^{73}$ The canon of Laon who had suggested that John was named after St John the Evangelist seems, therefore, to have been right but for the wrong reason. ${ }^{74}$ It is also noteworthy that John's elder sister, Joanna, born in October 1165, was also named after this saint; in the mid-1160s Johanna / Johannes (Latin) Jehannette / Jehan (Old French) was the name destined for Eleanor and

\footnotetext{
$72 \quad$ Church, King John, p. 1.

73 ' cum vidisset ergo Iesus matrem et discipulum stantem quem diligebat dicit matri suae mulier ecce filius tuus' 'deinde dicit discipulo ecce mater tua et ex illa hora accepit eam discipulus in sua' (Vulgate Bible, John, xix, 26-7).

$74 \quad$ Recueil des historiens des Gaules et de la France, XIII, p. 679.
} 
Henry's next child, whether female or male. ${ }^{75}$ And both children spent time at Fontevraud during the formative years of their education. ${ }^{76}$

S. D. CHURCH

University of East Anglia

75 E. A. R. Brown, 'Eleanor as Parent, Queen and Duchess', in Eleanor of Aquitaine: Patron and Politician, ed. W. W. Kibler (Auten, Tx, 1976), pp. 9-34 (at 17).

76 For John's early years, see Church, King John, pp. 4-7 (dating John's time at

Fontevraud to the period 1172-7); for Joanna see Colette Bowie, The Daughters of Henry II and Eleanor of Aquitaine (Turnhout, 2014), p. 35. 